\begin{tabular}{|c|c|c|c|c|c|c|c|c|c|}
\hline \multirow[b]{2}{*}{ Screening policy } & \multirow[b]{2}{*}{$\begin{array}{l}\text { Unaffected } \\
\text { births }\end{array}$} & \multicolumn{3}{|c|}{ Down's syndrome } & \multicolumn{2}{|c|}{ Amniocentesis } & \multicolumn{2}{|c|}{ Programme costs } & \multirow{2}{*}{$\begin{array}{c}\text { Miscarriages } \\
\text { induced by } \\
\text { amniocentesis } \\
\text { per case of } \\
\text { Down's syndrome detected }\end{array}$} \\
\hline & & Births & Miscarriages & $\begin{array}{c}\text { Cases } \\
\text { detected }\end{array}$ & $\begin{array}{l}\text { No } \\
\text { carried } \\
\text { out }\end{array}$ & $\begin{array}{l}\text { Miscarriages } \\
\text { induced }\end{array}$ & $\begin{array}{c}\text { Total } \\
(£ 000)\end{array}$ & $\begin{array}{l}\text { Per case of Down's } \\
\text { syndrome detected } \\
(£ 000)\end{array}$ & \\
\hline Offer serum testing to all pregnant women ${ }^{\star}$ & 7440 & $5 \cdot 8$ & 1.9 & 6.9 & 373 & $3 \cdot 73$ & 180 & 26 & 0.50 \\
\hline Offer serum test to all women aged 30 and over* & 7441 & 6.5 & $2 \cdot 1$ & $5 \cdot 8$ & 284 & $2 \cdot 84$ & 105 & 18 & 0.49 \\
\hline
\end{tabular}

${ }^{\star}$ High risk defined as risk $>1: 250$.

model by applying population based values for specificity and sensitivity that are independent of age may greatly alter the conclusions that are drawn from the model. We have recalculated the decision analysis using age specific values (table).

The recalculated numbers do not materially alter the results of the analysis: offering biochemical testing to all women would still prevent the birth of about one more baby with Down's syndrome in Oxfordshire than would a policy of offering biochemical testing for women aged 30 and over. The recalculated cost of preventing this one extra birth is $£ 75000$ (compared with $£ 90000$ in the original calculation) and one normal fetus lost after amniocentesis (previously one or two). In addition, Wald and colleagues' figures confirm that the number of miscarriages induced by amniocentesis per case of Down's syndrome detected remains higher for the option of screening women of all ages.

The conclusion that we draw from the model remains unaltered: although, among the options that we considered, the option of offering biochemical testing for women aged 30 and over best meets the predetermined criteria set by our health authority, these criteria did not take the views and values of individual women into account. Our conclusion was that the rigid application of any one policy option to all women is inappropriate. We wrote that "if the needs of individuals are not to be subjugated to those of the population, serum testing should be an option for all pregnant women and its use determined by the individual preferences of well informed women." If our article is interpreted as advocating a policy based on age then it has been misunderstood. We still believe that the use of serum testing for Down's syndrome should be determined by the views and values of well informed women and not by their age.

Wald and colleagues' criticism is based on the view that a quantitative comparison requires that either the population detection rate or the population false positive rate should be held constant among the options under consideration. The implication of this is that these are the most important outcomes of screening. As, in our experience, people do not agree about which outcomes are most important, we attempted to avoid making any such assumptions in our analysis.

Murray and Tennison question the reporting of the numbers in the abstract of our paper. The abstract refers to the costs of preventing births of infants with Down's syndrome and not cases detected, as they have assumed.

J FLETCHER Senior registrar in public health medicine N R HICKS

Consultant public health physician Department of Public Health and Health Policy, Oxfordshire Health, Oxford OX3 7LG

J D S KAY

Consultant chemical pathologis

Department of Clinical Biochemistry,

Oxford Radcliffe Hospital,

Oxford OX3 9DU

PA BOYD

Clinical coordinator for prenatal diagnosis Maternity Department, Oxford Radcliffe Hospital

1 Royal College of Obsterricians and Gynaecologists Scientific Advisory Committee Working Party. Biochemical detection of Down's syndrome. London: RCOG, 1993.

\section{Right to choose}

EdrTor,-I was distressed to read Liam Farrell's piece about the issue of abortion in the Republic of Ireland.' It includes the allegation that "the opponents of abortion are usually right wing neofascist, religious fundamentalist lunatics, also opposed to contraception, sexual freedom, and euthanasia and in favour of capital punishment." For good measure he adds at the end of the paragraph that we are "bloody hypocrites." He gives no evidence to support this offensive allegation.

As vice president of the Society for the Protection of Unborn Children I have met many thousands of members since 1967. Most are left wing and against capital punishment; many are religious (and they include members of all faiths), but many are not. Their attitude to contraception varies, but the society takes no stand on contraception any more than it does on ecology. Farrell does not define "sexual freedom," but we have members who are homosexual. As there are millions of opponents of abortion it is impossible to guarantee that none of them are bloody hypocrites or in favour of capital punishment because the pro-life movement consists of all sorts of people united in their objection to the fascistic policy, so prevalent today, of killing unborn babies who are disabled or unwanted. Four million unborn babies have been killed since 1967.

There is a further inaccuracy in the first paragraph of the article: therapeutic abortion is legal in Northern Ireland. The law there is the same as it was in England before the Abortion Act of 1967.

MARGARET WHITE

Croydon,

Retired general practitioner

Surrey CR0 5DQ

1 Farrell L. Right to choose? BMf 1995;311:457. (12 August.)

\section{GMSC's extraordinary general meeting}

Date and venue of meeting timed to favour status quo

EDrToR,-The proposal that democracy will be better served if regional representatives of the General Medical Services Committee are directly elected by all general practitioners divided into appropriate large constituencies has much merit. The fact that the issue has not been given a suitable airing at the conference of local medical committees or the BMA's annual representative meeting has led to an extraordinary general meeting being called.

As this is an extraordinary general meeting and all members of the association are entitled to attend, no expenses are payable. It therefore seems a travesty of democracy that it is being held on a day when the GMSC is meeting, when all its members will have received expenses and an honorarium for attending. Those with the greatest interest in maintaining the status quo will already be in London ready to defend their vested interest at the expense of the general membership. A case could be made for holding such a meeting at a time when no member had any advantage at a venue more central in Britain.

The articles of association may have been satis- fied in the calling of this meeting, but the democratic process and general ethos of fair play certainly have not.

CHRISTOPHER TIARKS Small Isles Medical Practice, Isle of Eigg PH42 4RI

\section{BMA secretary's reply}

EDITOR,-Christopher Tiarks is a senior member of the BMA's council, and it is unfortunate that he could not be present at the council's last meeting, on 14 October. Had he been, he would know that all the points raised in his letter were covered in the full debate that the council had on the arrangements for the extraordinary general meeting called by Dr David Roberts and his 100 supporters.

Tiarks's letter contains an important error, which I wish to correct. He says "that the issue has not been given a suitable airing at the conference of local medical committees or the BMA's annual representative meeting." In fact, 17 motions were submitted to the annual conference of representatives of local medical committees on 21 and 22 June 1995 , and these were the subject of three very full debates, in which Dr Roberts himself played a leading part. The outcome was that the conference decided: (1) that the arrangements for the election of regional representaitves on the General Medical Services Committee should be changed to be (a) triennial and $(b)$ by election of one third of the members each year; (2) that the 16 seats for members of the GMSC elected by the conference of local medical committees and the annual representative meeting should remain unchanged; and (3) that the conference believes that the following principles should apply if the GMSC's electoral arrangements are to be altered: $(a)$ the position of the GMSC as a standing committee of the BMA should be maintained; $(b)$ the direct relationship between the GMSC and local medical committees should be strengthened; $(c)$ more positive arrangements should be made for members of the GMSC to attend meetings of local medical committess that are not directly represented on the GMSC; and (d) the position of local medical committees as collectors of the quota for the General Medical Services Defence Fund should be maintained.

In respect of the annual representative meeting in Harrogate this year, the simple fact is that not one of the 531 motions submitted for consideration dealt with reform of the GMSC. As I have pointed out on several occasions to council members, including Tiarks and Dr Roberts, only the annual representative meeting has the power to change schedule 2 to the byelaws and thus affect the constitution of the GMSC. Neither Tiarks's division nor Dr Roberts's division nor, indeed, any other constituency brought the matter forward for consideration. As I have also pointed out on several occasions, the extraordinary general meeting next week will not affect this basic process. Under the current articles, only the annual representative meeting has the power to change the byelaws. Thus if the membership wishes to give this issue "a suitable airing" then the only practical mechanism that could lead to action is to ensure that it is raised at next year's annual representative meeting.

E M ARMSTRONG

BMA House, Secretary

London WC1H 9JR 